\title{
Entering Parcel Boundaries into the Polish Register of Land and Buildings - an Analysis of the Current State and Proposed Changes ${ }^{2}$
}

\begin{abstract}
The Polish register of land and buildings (EGiB), also known as the real estate cadastre, is of both a technical and declarative nature, which means that the data resulting from special technical, formal and legal procedures should be precisely entered into the EGiB database and then made available to users without distortions or deficiencies. The subject of this research paper is the analysis of formal, legal and technical problems that occur in the process of entering data on the boundaries of cadastral parcels into EGiB. Based on the legal provisions, subject literature, as well as real cases derived from surveying practice, the author performs a descriptive formal and comparative analysis of current legal and technical solutions used to enter boundaries of cadastral parcels into the EGiB database. As a result of these analyses, the author has concluded that the existing legal solutions allow neither full and precise entering of parcel boundaries nor providing users with correct data resulting from the performed surveys and legal works. Defects, difficulties and barriers faced when entering boundary data into the register can lead to the distortion of the relevant information, and thus to the decreased reliability of EGiB. The author's proposal is to introduce into the application schema the concept of the boundary segment, together with appropriate attributes defining the structure of the cadastral database. This would allow the elimination of many existing problems and provide EGiB users with reliable and complete information.
\end{abstract}

Keywords: cadastre, register of land and building, boundaries of cadastral parcels, boundary points of parcels

Received: 15 March 2020; accepted: 18 April 2020

(C) 2020 Author. This is an open access publication, which can be used, distributed and reproduced in any medium according to the Creative Commons CC-BY 4.0 License.

1 AGH University of Science and Technology, Faculty of Mining Surveying and Environmental Engineering, Krakow, Poland, email: podwilk@agh.edu.pl

ORCID ID: https://orcid.org/0000-0002-7317-0292

2 The article was prepared under the research subvention of AGH University of Science and Technology No. 16.16.150.545 in 2020 


\section{Introduction}

In Poland, the data on the boundaries of cadastral parcels of the register of land and buildings (EGiB), also known as the real estate cadastre, are entered into the EGiB survey. Pursuant to the Ordinance [1], in force until 14 January 1997, the EGiB survey (cadastral survey) could only function in an analogue (paper) form and consisted of a cartographic part (cadastral map) and a descriptive and tabular part, called the descriptive part, containing documents such as: land records, plot index, land list and a set of files being the basis for entries made in the land records. It was the Regulation [2] that introduced the possibility and obligation to keep the EGiB survey in a digital form as a computer database covering both descriptive data and a numerical map containing geometric (cartographic) data on 15 January 1997. Geometric data regarding boundaries of cadastral parcels had to be recorded in vector form in accordance with the Technical Guideline K-1 [3, 4], which became an Appendix to the Regulation [5] in 1999.

It should be noted that the above-mentioned Regulation on EGiB [2], constituting the executive orders to the Act of 17 May 1989 Geodetic and Cartographic Law [6], far exceeded the regulations contained in this Act, which was a serious violation of the principles of the creation and hierarchy of legal (normative) acts. In the Geodetic and Cartographic Law [6], until 18 October 2010, there was only a statement that the cadastral survey shall "consist of maps, records and documents justifying entries in these registers". Thorough changes introduced in numerous legal regulations as a result of the so-called transposition of the INSPIRE directive $[7,8]$ into the Polish legal order meant that also the Act [6] finally included a provision fully sanctioning the digital form of the EGiB survey.

Since 19 October 2010, the EGiB survey has consisted of two elements [6]:

- a database covering the EGiB data, kept by means of an ICT system that meets the requirements set out in [6],

- a set of documents justifying entries into the EGiB database.

It should be mentioned that, since 23 February 2000, pursuant to [6], the register of land and buildings in Poland (EGiB) has also been additionally called "the real estate cadastre".

Figure 1 schematically illustrates the composition of the cadastral survey, also demonstrating a fragment of the flow of documents (reports) and data towards their recipients (users) such as property owners, tax authorities, and district courts keeping land and mortgage registers. Based on the documents delivered to the authorities that keep the register of land and buildings, i.e. district governors or presidents of cities with county rights, the content of the EGiB database is supplemented or modified on an ongoing basis, and then it reaches users (recipients) in the form of official digital data saved in the GML format or reports saved in the form of documents (extracts, drawings, lists). 


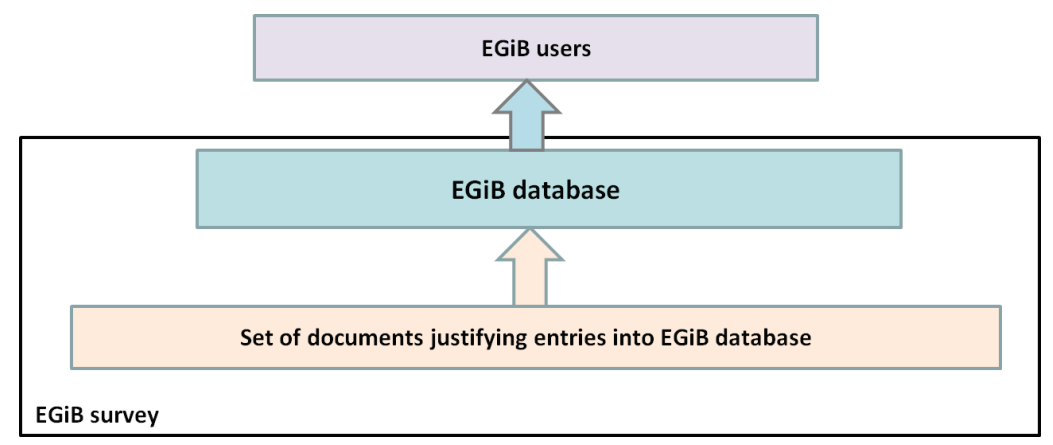

Fig. 1. Diagram of the composition of the EGiB survey and of the flow of data and documents to the user

Source: own study based on [6]

The quality and reliability of the data obtained by users from the EGiB database depends on:

- the quality of the data itself resulting from documents (survey reports), constituting the basis for changes introduced into the EGiB database,

- the correctness of the entry of the above data into the EGiB database,

- the possibility to precisely enter the data into the EGiB database, resulting from available objects, structures and relationships,

- the correctness of generating and saving the data in a user-readable way.

A full analysis of the occurring threats to data reliability would require an analysis of all the above-mentioned issues, which exceeds the framework and subject of this research paper. Some aspects of such analysis have already been presented, e.g. in [9-12]. This article focuses on the analysis of methods of entering data on boundaries of cadastral parcels into the EGiB database, especially the data describing the basic linear elements of these boundaries in the form of segments. The cadastral boundary segment is defined by the two nearest turning points [13], currently represented in the EGiB database by spatial objects (classes of the "FeatureType" stereotype) called "EGB_PunktGraniczny" [14]. The boundary of the cadastral parcel is "part of the perimeter of the cadastral parcel in the form of a broken line or a segment, common to two adjacent cadastral plots of land" [14]. The definition of the boundary of the cadastral parcel was introduced into the Regulation and has been binding since 31 December 2013 [15].

The digital form of data has widely known advantages and is incomparably more convenient to store, process and share than the analogue paper form. From the user's perspective, quick access to reliable data, which is a source of various types of information necessary to make accurate decisions, is essential. EGiB is of particular importance in the Polish spatial data infrastructure. Reliable data ensure security of real estate transactions and accelerate the pace of preparation and implementation of infrastructure investments $[7,16]$. 
It is, undoubtedly, much easier to accelerate access to data for a wide group of recipients, using digital recording, ICT systems and relevant legal regulations. The positive effect of the INSPIRE Directive and the Act of 4 March 2010 on Spatial Data Infrastructure [8] on the change and significant modernisation of the Polish legal provisions cannot be overestimated in this respect. The Directive [7] and the Act on Spatial Data Infrastructure [8] have abolished many unnecessary formal and legal barriers that were present in Poland for years and allowed legal access to data using various types of geoportals, both at local and national levels.

\section{Materials and Methods}

The subject of the research is the influence of the structure of the EGiB database recorded in the form of an application schema in the EGiB Regulation [14] on the reliability of the EGiB data on parcel boundaries, and specifically on entering linear elements in the form of boundary segments into the EGiB database. The author hypothesises that the EGiB application schema in force in Poland is incorrect, since it does not allow for the proper recording of information on the boundaries of cadastral parcels, and as a result, the data provided to users are distorted and unreliable.

Descriptive analyses were used, known e.g. from the legal sciences, including:

- literal analysis,

- system analysis,

- functional analysis,

- comparative analysis.

There is no legal definition of the reliability of the EGiB data in Poland, i.e. such a definition does not exist in the provisions of applicable laws, despite the fact that this term is used in the Regulation itself [14] to qualify which parcel boundaries must be subject to the procedure of determining their course due to the lack of reliable data. This concept, just like e.g. "good faith" or "principles of social coexistence", belongs to the so-called general clauses used in legal regulations [17, 18]. Reaching into the dictionary meaning $[19,20]$ of the word, it should be pointed out that the data, understood as information carriers, are reliable if the user can trust that they present a true picture of the situation or otherwise present the actual state. Gaździcki defines reliability as "compliance within the limits of permissible measurement errors between information obtained based on system data and the actual state at the time of capturing the data. Non-compliance may be due to lack of timeliness and any type of error" [21].

In land surveying, "true" or "real" data are usually associated with very accurate data regarding length, directions, angles, or coordinates of points, i.e. high-accuracy data. Even such data cannot be considered "completely true" because they are encumbered with a certain, although relatively small, degree of inaccuracy (in other words - they are encumbered with a "minor error"). In surveying practice, as far as 
data describing the location and course of cadastral parcel boundaries are concerned, rarely do we deal with "true" data, free from any errors. Therefore, additional parameters (attributes) are used that inform the data user about the value of this inaccuracy, using the parameters known from mathematical statistics or the equalisation calculus commonly used in geodesy. The data are therefore characterised through standard deviations and confidence intervals. Therefore, the "main" data, such as arithmetic mean, should be accompanied by additional attributes (metadata) that characterise them. Only such a "set" of data and their attributes make it possible for the user to assess the degree of their reliability and the scope of their potential use (Fig. 2).

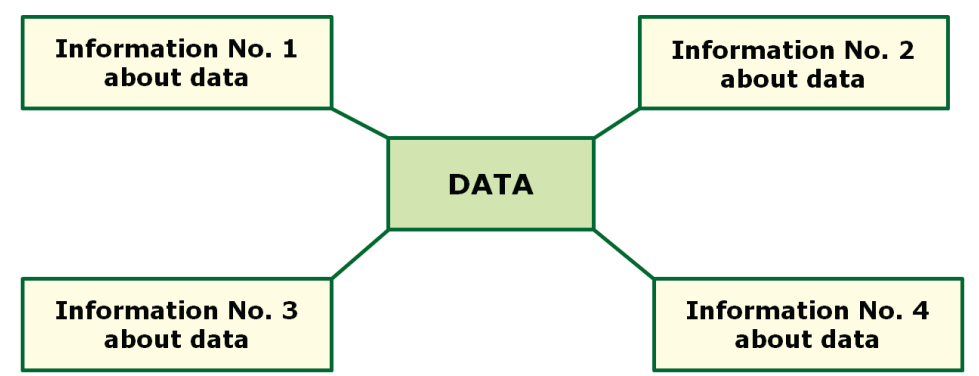

Fig. 2. Illustrative schematic diagram of elementary data described by additional information (metadata), which allow e.g. to determine its reliability

More on the criteria for assessing data quality and their reliability was written in [22], with reference to the extensive subject literature, including ISO 19000 standards. However, it should be noted that the reliability of data is assessed by a "living recipient" of this data, i.e. a person, who is guided not only by their needs, but also by their knowledge and life experience, and frequently by personal knowledge of the author of the data. This means that this recipient is able to "add" appropriate metadata to the data obtained and, at least partially, assess their reliability. In the case of computer data processing, it is impossible or very difficult to interpret these data correctly if the source database lacks the appropriate attributes (metadata). This lack may be due to the following reasons:

- it is not possible to obtain appropriate data attributes, or attributes entered into the database are incorrect;

- incorrectly designed database structure (application schema) or any incorrect amendments to legal regulations made correct data and their attributes currently occur in the wrong context or incorrect meaning (e.g. in amended legal regulations, attributes have been assigned a different meaning than they had before or the same value of the attribute has been assigned to data with completely different characteristics) [11, 23-25];

- lack of fields or relationships in the database structure that would allow to record appropriate attributes enabling correct and full data characterisation [23-25]. 
Particularly great damage to the reliability of the EGiB data is caused by the last two of the above-mentioned cases, because they affect almost all data (the entire database), not just individual data, as in the first case. This leads to systemic, official and mass distortions of data, and consequently to both the decreased reliability of the entire database as well as to the waste of forces and resources, often public, intended to maintain EGiB databases.

\section{Discussion}

Attributes having the character of metadata of boundary points of cadastral parcels were introduced to EGiB by the Regulation of 29 March 2001 on the register of land and buildings [14] as late as on 2 June 2001. This Regulation allowed that, during the transitional period of creating digital EGiB databases, coordinates of boundary points of the accuracy lower than basically required by the then regulations, can be entered into the EGiB database (instead of the required $0.10 \mathrm{~m}, 0.60 \mathrm{~m}$ was adopted for urban areas and $3.0 \mathrm{~m}$ for rural areas). Thorough and extensive amendments introduced to the above-mentioned Regulation in 2013 and 2016 [15, 26], on the one hand removed a lot of these shortcomings and defects, but on the other hand they caused chaos in EGiB databases, due to the lack of an evolutionary approach to introducing changes, e.g. in the form of appropriate transitional provisions. Fairly vivid examples in this regard are, unfortunately, the attributes (Matadata) of the object "EGB_PunktGraniczny", which was described also in [9-11, 22-24]. The authors of the IT systems in Poland used for store EGiB databases are trying hard to maintain the proper meaning of the data within the source databases functioning in cadastral bodies, sometimes even going beyond the legally binding, rigid application schemas. This applies, for example, to the description of the "BPP" attribute (mean boundary point position error relative to the geodetic control - full name in the application schema: "bladPolozeniaWzgledemOsnowy"), according to the "old" scale of values valid until 31 December 2013 which, for example, in the EWMAPA programme of GEOBID are referred to as "G5BPP". However, the export and subsequent import of the EGiB data made in the applicable GML format and in accordance with the applicable application schema specified in [14], leads to a "combination" of these "old" and "new" attributes. Hence, in [23, 25], specific solutions were proposed to prevent the blurring of significant differences among data, and thus to also prevent misleading both users and IT systems that perform "mechanically" various types of calculations and analyses based on these data.

Unfortunately, such threats have already been expressed in disputes between surveying contractors and the authorities who provide them with the EGiB data needed to carry out these works. It is exemplified e.g. by the position of the Provincial Administrative Court (WSA) in Krakow in 2018, which stated that: "Administrative authorities, knowing that the data to be made available to the claimant may not 
allow reliable determination of boundary points, should not only have informed the claimant of this without incurring costs for obtaining these materials, and without bearing the costs of all the work done, but above all they should have updated them ex officio. The court emphasises that under no circumstances may the actions of administrative bodies constitute a kind of a "trap" for a citizen, and this is the kind of action that the court sees in this case" [27].

The reliability of the EGiB data is ensured by the "double" check procedure applied to geodetic data before they are entered into the EGiB database, which results directly from the provisions of the Act [6]. If the data regarding BDOT500 or GESUT databases, defined in [6], are provided by the surveying contractor to the County Geodetic and Cartographic Documentation Centre (PODGiK), after positive verification by PODGiK, these data are entered (recorded) directly in the official database of the National Geodetic and Cartographic Resource (PZGiK). In the case of the EGiB data, these data are additionally verified by the Department of Cadastre of the District Governor's Office and entered into the EGiB database only by means of an update performed in two separate modes (Fig. 3):

- by way of material and technical change - a relatively quick procedure that does not require the involvement of property owners (or more broadly interested cadastral entities), or

- by way of full administrative proceeding ended with a final decision to amend the EGiB survey report - in the absence of a motion from interested parties [6].

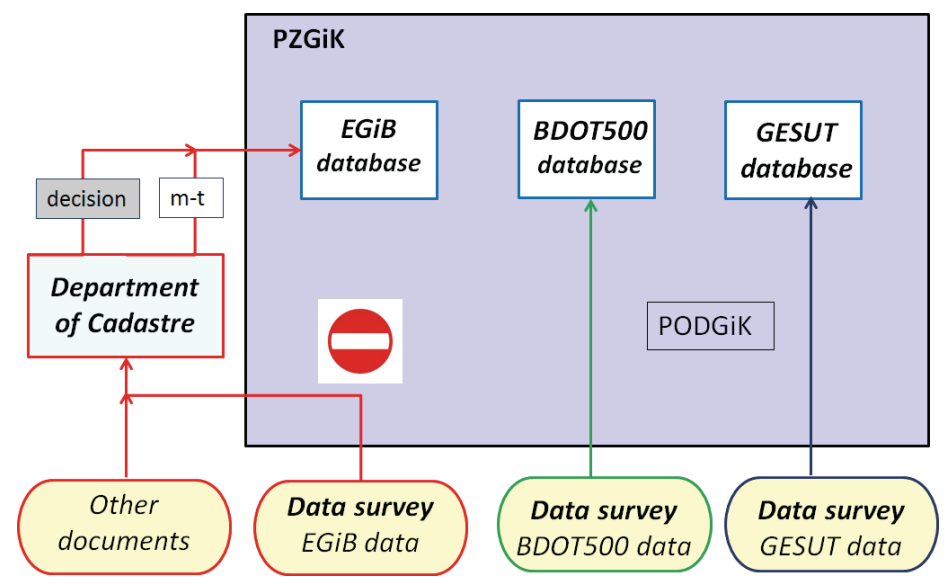

Fig. 3. Illustrative diagram of data flow to PZGiK ("m-t" - material-technical)

Source: own study based on [6]

The Department of Cadastre of the District Governor's Office acting on behalf of the District Governor may refuse to introduce changes into the EGiB database despite the fact that the survey containing these data has been positively verified 
and accepted by the National Geodetic and Cartographic Resource. It results from a different type and scope of "control" that this department uses, when compared to the technical scope of "verification" carried out by the County Geodetic and Cartographic Documentation Centre [28, 29].

One of the data sets made available by the European Union (EU) member states for the needs of INSPIRE are Cadastral Parcels. The following spatial object types shall be used for the exchange and classification of spatial objects from data sets that relate to the spatial data theme Cadastral Parcels [30] (Fig. 4):

- Basic Property Unit (auxiliary) - basic property units are the basic units of ownership that are recorded in the land books, land registers or equivalent;

- Cadastral Boundary (auxiliary) - part of the outline of a cadastral parcel. One cadastral boundary may be shared by two neighbouring cadastral parcels. In the INSPIRE context, cadastral boundaries are to be made available by member states where absolute positional accuracy information is recorded for the cadastral boundary (attribute estimated accuracy);

- Cadastral Parcel (core) - cadastral parcels are defined by the INSPIRE Directive as "areas defined by cadastral registers or equivalent". Single areas on Earth surface under unique or homogeneous property right, forming as much of possible a partition of territory. Cadastral Parcels shall always be made available;

- Cadastral Zoning (auxiliary) - cadastral zonings are the intermediary areas (such as municipalities, segments, blocks, ...) used in order to divide national territory into cadastral parcels.

\begin{tabular}{|c|}
\multicolumn{1}{|c|}{\begin{tabular}{c}
\multicolumn{1}{c|}{ "featureType» } \\
CadastralBoundary
\end{tabular}} \\
\hline$+\quad$ geometry: GM_Curve \\
$+\quad$ inspireld: Identifier [0..1] \\
«lifeCyclelnfo, voidable» \\
$+\quad$ beginLifespanVersion: DateTime \\
$+\quad$ endLifespanVersion: DateTime [0..1] \\
«voidable» \\
$+\quad$ estimatedAccuracy: Length [0..1] \\
$+\quad$ validFrom: DateTime [0..1] \\
$+\quad$ validTo: DateTime [0..1] \\
\hline constraints \\
$\left\{\begin{array}{l}\{\text { estimatedAccuracyUoM } \\
\{\text { validTo\} } \\
\{\text { endLifespanVersion }\}\end{array}\right.$ \\
\hline
\end{tabular}

Fig. 4. UML class diagram: overview of the Cadastral Parcels application schema Source: Chapter 5 of [30] 
Due to the fact that the INSPIRE Directive [7] was adopted essentially for the purposes of environmental protection in the European Community and not for the implementation of the tasks of the real estate cadastre, it does not require that information about parcel boundaries be compulsorily created and made available as separate objects ("Cadastral Boundary" classes). The purpose of providing access to data sets and services within INSPIRE, different from the cadastral one, is confirmed by the requirements set by the INSPIRE specification in the scope of accuracy in determining the coordinates of points of cadastral parcels [30], which are relatively low and generally incompatible with the Polish legal regulations regarding the register of land and buildings.

Minimum data quality results for spatial data theme "Cadastral Parcels" - positional accuracy as absolute external accuracy (mean value of positional uncertainties):

- min. 1 metre in urban areas,

- min. 2.5 metres in rural/agricultural areas.

On 31 December 2013, the following definition of the cadastral parcel boundary was introduced to the Regulation on EGiB [14]: "part of the perimeter of the cadastral parcel, in the form of a broken line or a segment, common to two adjacent cadastral parcels or coinciding with the state boundary - in the case of plots of land adjacent to this boundary". This definition is modelled on the INSPIRE specification [30] and does not take into account the fact that the so-called corner boundary points often belong not only to two, but to a larger number of parcels, which creates specific requirements as well as technical and formal problems described e.g. in [9]. The definition of the parcel boundary introduced into the Regulation on EGiB [14] was not reflected in the basic component of the EGiB survey report, which is the database. No appropriate classes or relationships have been introduced to the application schema that would allow to record this type of information about boundaries in the EGiB database, including the information about elementary segments of boundaries. Therefore, the course of boundaries is still entered into the Polish EGiB exclusively with the help of the "EGB_PunktGraniczny" class that concerns only the (end) points of boundary segments. Such a solution is even contrary to $\S 39$ section 3 of the same Regulation [14], which requires that "information on disputed segments of boundaries of cadastral parcels be entered into the cadastral database". Neither in the Regulation on EGiB itself nor in the Regulation [31] defining cartographic codes and signs used on base maps, have the required solutions enabling automatic implementation of this requirement in ICT systems managing EGiB databases been included. This is all the more unreasonable since the Guideline K-1 [3, 4], which was in force until 8 June 2012, displayed an optional cartographic sign called "GDS" allowing the representation of the disputed boundary on the numerical map (Fig. 5).

It should be noted that the Act on PGiK uses the concept of "boundary lines" of real estate based on boundary points [6], while the Regulation on EGiB, when 
defining a cadastral parcel, does not refer to the concept of a parcel boundary contained in that Regulation, but to undefined "boundary lines" as elements separating the parcel from the surroundings $[9,14]$. According to the author of the research paper, the basic linear element describing the parcel boundary in the EGiB database, which is in a proper relationship with the boundary point already present in the EGiB application schema ("EGB_PunktGraniczny" class), should be a boundary segment and not the "entire" boundary, sometimes being a broken line consisting of several or even several hundred segments. The adoption of the boundary segment as a basic element for parcel boundaries in the register of land and buildings (elementary class with appropriate attributes), as proposed by the author, will have many legal, technical and practical advantages, described briefly below.

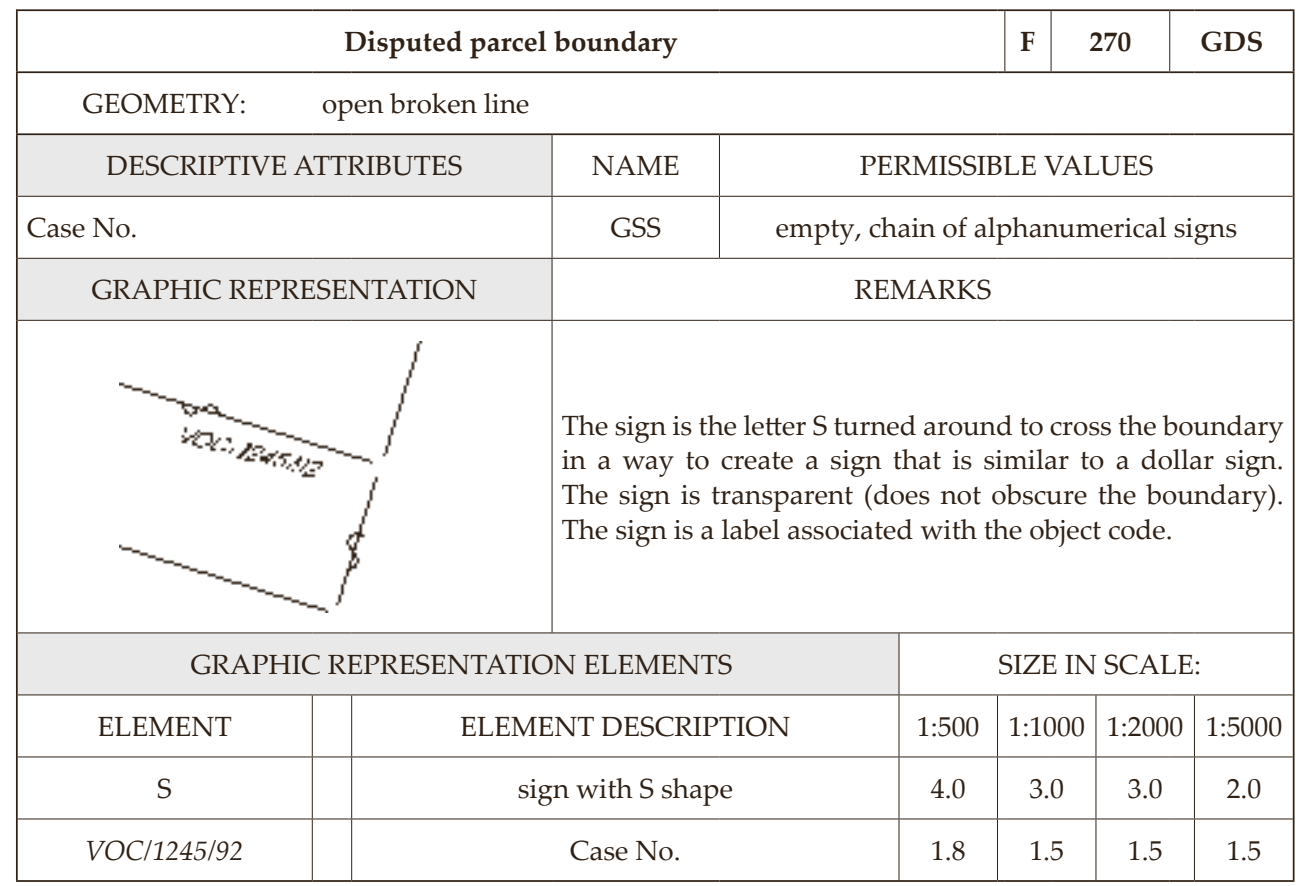

Fig. 5. Cartographic sign regarding disputed parcel boundary

Source: [4]

"All or some of the boundaries of a specific real estate with adjacent real properties or other land, if necessary, shall be subject to..." [6] real estate delimitation carried out pursuant to the Geodetic and Cartographic Law. Delimitation may, therefore, concern e.g. only one of the boundaries of the cadastral parcel that is part of the land property or a single segment of this boundary which has become the subject of a neighbourly dispute. If there is no data in the EGiB database kept by PODGiK regarding the other boundaries of this parcel (e.g. EGiB has not been 
modernised and there is still a cadastral map in paper or raster form for this cadastral area), such a single boundary cannot be officially entered into the EGiB database. There is no such class in the current EGiB application schema [14], or a cartographic sign or code [31]. This is a very serious omission and oversight on the part of the legislator, because boundaries established as a result of delimitation proceedings have the highest rank and legal significance (these are the most reliable and certain boundaries, which is expressed in them frequently being defined "legal boundaries").

In the absence of reliable data, and if taken literally, the Regulation on EGiB [14] requires one to determine the course of the "entire" boundary, and not selected, individual segments affected by these unreliable data or those segments of the boundary which, for justified reasons, require such determination, e.g. for the need of property subdivision or erecting buildings at a distance of less than 4 meters from the boundary (c.f. § 79 section 6 of the Regulation on standards [32]). This is confirmed by the model protocol for establishing the course of parcel boundaries, together with examples of entries, constituting Appendix 3 to the Regulation [14] (the form of this protocol and the mentioned exemplary entries have already been subjected to critical analysis in [9]). This situation leads to surveying contractors being unjustly forced to carry out costly and time-consuming activities that have no justification or statutory authorisation.

In the case of real estate subdivision under the Real Estate Management Act [33], the legislator noticed the problem indicated above and adopted a solution allowing a rational limitation of the scope of surveying works by referring to the concept of the boundary segment defined in the executive regulation to this Act [13]. If real estate subdivision consists in the parcelling out of a plot of land with an area of up to $33 \%$ of the real estate subject to this subdivision, then the activities of the "acceptance" of the course of boundaries (this is not a formal "determination") are carried out only for those segments of the real property boundaries which are reached by the proposed subdivision boundaries [13]. The Regulation on standards [32] prepared similar solutions for the purpose of calculating, in a simplified manner (by the so-called deduction or subtraction), the area of plots parcelled out from agricultural or forest properties, whose total area does not exceed 33\% of the total area of the real estate subject to subdivision (§ 77 section 7 of the Regulation [32]). Unfortunately, § 61 section 1 of the Regulation on EGiB [14] explicitly states that the numerical description of the boundaries of cadastral parcels: "is performed with the help of appropriate sets of boundary points whose location relative to the first-order geodetic control was determined based on plane land surveys with mean errors not exceeding $0.30 \mathrm{~m}$, in a manner ensuring the mapping of the position and shape of these spatial objects as well as interrelationships between them". Any deviations in this respect are only allowed during the transitional period and apply exclusively to the EGiB modernisation procedure carried out at the request of the district governor for areas covering at least one cadastral district ( $\$ 82$ of the Regulation [14]). 
Such a stringent and difficult to implement requirement has numerous and various consequences. It is not difficult to imagine a frequently occurring task of widening a road lane by parcelling out small fragments of land from many private plots adjacent to the road plot, with surface areas of several or several dozen square meters (e.g. the so-called "ZRID" procedure - a decision on a permission for the implementation of a road investment - based on the special purpose Road Act [34]). If, additionally, the parcels being subdivided have very complex boundaries consisting of many segments, then determining their course becomes not only a costly and time-consuming task, but also a socially complicated one, because it affects many neighbourly relations. In this case, it seems reasonable to ask whether public funds are really to be used to establish boundaries between "private" properties that do not even touch the road lane at any point. Possible allegations put forth by control bodies of improper spending (wasting) of public money are also difficult to refute. The argument based on the requirements ("wishes") contained in the provision of the regulation's rank is insufficient, mainly resulting from the limited possibilities of storing data in the EGiB database constructed in a faulty manner.

Literal enforcement of the requirements of the above-mentioned $\S 61$ section 1 of the Regulation [14] by district governors caused a very heated discussion and numerous protests in the geodetic environment, and even appeals to administrative courts. Surveyors pointed to the negative consequences of such a solution for investors, including public investors, due to the significant increase in costs and the extension of the time needed to perform real estate subdivision [35]. The Provincial Administrative Court (WSA) in Gliwice, however, pursuant to applicable legal regulations, confirmed the need to apply this provision [36, 37].

In the Regulation on EGiB, there are only two objects "EGB_DzialkaEwidencyjna" and "EGB_PunktGraniczny", called classes in UML (Unified Modeling Language), directly related to the description of the geometry of the cadastral parcel. In the application schema written in the UML and included in the Regulation [14], for the diagram "DzialkaKlasouzytek" (restriction called: "wymagalnoscGeoreferencjiIGeometrii"), it was provided that the parcel could be represented in the EGiB database by one of the attributes:

- "georeference" - georeferenced point "GM_Point" or

- "geometry" - the surface object "GM_Surface".

It should also be noted that the first case, i.e. representing a parcel only by the so-called centroid visible to the user in the form of the parcel identifier (e.g. 120616_2.0023.123/1), is inconsistent with the parcel definition and with the previously mentioned stringent requirements for numerical description of parcel boundaries in the EGiB database. Such a discrepancy proves that this legal provision is not of the best quality or consistency.

The lack of a class regarding the boundary segment in the application schema is visible e.g. when surveying contractors are serviced by PODGiK and when the data 
of the EGiB database is edited. Surveyors who report the commencement of surveying works to PODGiK and request access to data necessary to perform these works, try to minimise the amount of fees incurred. Therefore, they use the spatial ranges of the reported works (polygons) with the smallest possible surface area, exceeding the boundaries of the parcel covered by the order barely by a few centimetres (the so-called subject parcel), despite the fact that details of neighbouring parcels are necessary for the correct implementation of the works. PODGiK must anyway provide them with geometrical data for the "entire" neighbouring parcels, often with large surface areas, because due to the application schema adopted in [14], it is not possible to export or import only parts of plots, i.e. certain boundaries or their selected segments. Therefore, district governors raised serious concerns about possible accusations put forth by control bodies regarding the reduction of income due to the State Treasury, an example of which is [10, 38].

The introduction of the boundary segment to the application schema, together with the appropriate attributes would allow the above problems to be solved and assuage fears. It should be mentioned that in the geodetic Guidelines K-1 of 1995 and 1998 in force until 8 June 2012, there was a similar object referring to a part of the parcel boundary called: "Część granicy działki" (numeric code "219" and letter code - "GDE") [3, 4, 10].

During the performance of the works by a land surveyor, the so-called blocking of "entire parcels" (without making any changes) is necessary in the IT system managing the EGiB database in PODGiK, so as to allow efficient, batch modification of the data based on a computer file provided by the contractor after completion of the works $[39,40]$. The need to block "entire parcels" leads to serious problems and complications due to the large number of survey reports submitted to PODGiK on an ongoing basis, which requires the efficient and parallel introduction of changes. This problem is also visible when several operators attempt to edit geometric data on parcels bordering many parcels (e.g. long road parcels), saved in one database covering the entire cadastral unit (usually one administrative commune) or the entire county. All boundaries of such a plot of land (the "entire parcel") are blocked then, even though the actual changes concern only a small part of it (e.g. several segments) [41]. Other operators are not able to make changes to the EGiB database at the same time if these changes regard other plots that adjoin at least one point to such a "blocked" parcel.

Legal and technical problems related to the lack of the boundary segment in the structure of the EGiB database will be presented using a fragment of an overview cadastral map containing boundaries and plot numbers as well as boundary point numbers (Fig. 6). Points with numbers 10 and 11 mark the parcel boundary consisting of one segment. In the EGiB database, functioning in accordance with the currently applicable application schema, the information about this boundary can only be saved in the form of boundary point attributes, while the attribute that is the most important from the analysed point of view with the code "ZRD" 
("zrodloDanychZRD" - boundary point location data source) applies only to the information on obtaining coordinates of points, thanks to which the point has been entered into the EGiB database [14]. However, this does not allow the information about the status of the boundary itself to be saved (e.g. determined, undetermined, not being determined, disputed, etc.) and about documents in which the course of this boundary has been described or approved (boundary protocols and sketches, real estate delimitation decisions, etc.) in the EGiB database. Documents of this type sometimes come from many years ago and do not allow directly to determine the coordinates of boundary points (e.g. boundary sketches with linear measures for permanent elements of land development), which makes them somewhat lost ("invisible") in the EGiB database regarding cartographic data. From a legal point of view, however, these documents still apply. They are attachments to final administrative decisions or final court decisions and allow for unambiguous restoration of boundary markers or determination of boundary points, which makes it possible to determine their coordinates. The usefulness of these documents to restore the course of boundaries in the field is sometimes much greater than of the documents that have such coordinates, but were prepared using geodetic controls and techniques applied many years ago that do not meet current accuracy requirements or were prepared for areas where horizontal and vertical movements of soils occur (displacements and deformations of land surface) caused e.g. by underground coal mining [42].

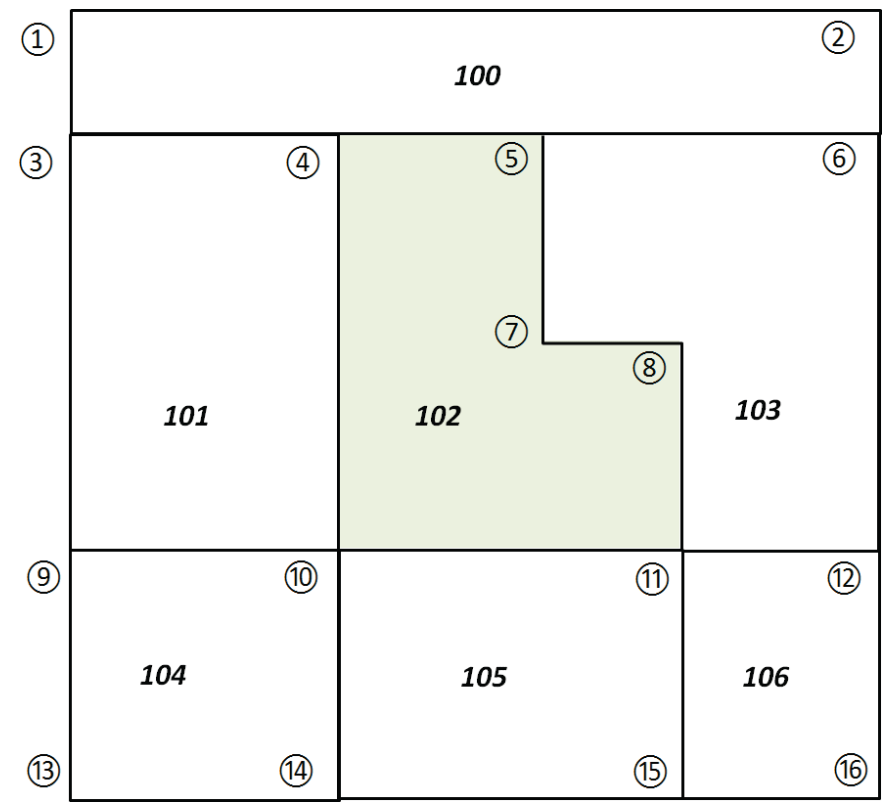

Fig. 6 Example of a map of the register of land and buildings Source: [10] 
It should also be emphasised that for real estate delimitation procedures, the documents containing numerical data (e.g. boundary sketches and protocols, measurement outlines) must first be used to determine the location of boundary points and the course of boundaries [43].

The inability to save attributes regarding e.g. the status of the boundary and reference to the identifiers of the documents that describe this boundary in the current database can lead to numerous mistakes and serious errors. This is presented in a demonstrative way in (Tab. 1), illustrating that with the same values of the ZRD attribute of the boundary points, the status of the boundary segment connecting them can be completely different.

Table 1. List of various values of ZRD attribute of boundary points and legal status of the boundary segment based on these points

\begin{tabular}{|c|c|c|c|c|}
\hline No. & $\begin{array}{l}\text { Value of ZRD } \\
\text { for point } \\
\text { No. } 10\end{array}$ & $\begin{array}{l}\text { Value of ZRD } \\
\text { for point } \\
\text { No. } 11\end{array}$ & $\begin{array}{l}\text { Description } \\
\text { of boundary } \\
\text { segment status }\end{array}$ & Remark \\
\hline 1 & 1 & 1 & determined & - \\
\hline 2 & 1 & 1 & $\begin{array}{l}\text { not being } \\
\text { determined }\end{array}$ & $\begin{array}{l}\text { Boundary not covered by appropriate } \\
\text { proceedings }\end{array}$ \\
\hline 3 & 1 & 8 & determined & $\begin{array}{l}\text { For point } 11 \text {, there are no coordinates } \\
\text { in the documentation - the point was } \\
\text { entered into EGiB database based on } \\
\text { vectorisation of an analogue map }\end{array}$ \\
\hline 4 & 8 & 8 & determined & $\begin{array}{l}\text { There are no point coordinates } \\
\text { in the boundary documentation }\end{array}$ \\
\hline 5 & 1 & 9 (dispute) & undetermined & - \\
\hline 6 & 9 (dispute) & 9 (dispute) & disputed & - \\
\hline 7 & 9 (dispute) & 9 (dispute) & $\begin{array}{l}\text { not being } \\
\text { determined }\end{array}$ & $\begin{array}{l}\text { Boundary not covered by proceedings. } \\
\text { Dispute concerns boundaries } \\
\text { of neighbouring parcels }\end{array}$ \\
\hline
\end{tabular}

For example, the second row of this Table demonstrates the case when the points 10 and 11 have a ZRD attribute in the EGiB database with the value " 1 ", which means that their coordinates result from the boundary determination procedure ("field surveys preceded by real estate delimitation procedures, restoration of boundary markers, determination of boundary points or determination of their location in another mode, including the procedure specified in $\S 39$ sections 1 and 2 of the Regulation" [14]). Despite that fact, the boundary itself was not covered by appropriate proceedings (e.g. delimitation) and it cannot be qualified as established, i.e. "certain" and reliable from the point of view of e.g. the owner of this property. The status of the points 10 and 11 may result, for instance, from delimitation proceedings, which formally covered the boundaries of the neighbouring parcels reaching the 
points 10 and 11. Therefore, the subject of the proceedings concluded with the final delimitation decision was not the course of the boundary from point 10 to point 11 . On the other hand, the fourth row of the Table 1 demonstrates a different case. The points 10 and 11 have relatively uncertain coordinates (ZRD equals " 8 ", i.e. "screen vectorisation of the cadastral raster map without using the results of geodetic field surveys" [14]), which may suggest to the cadastral map user that this boundary was not subject to determination proceedings. It turned out that the course of this boundary had been established a few years ago by appropriate legal procedures, but the documentation that had been prepared at the time did not currently allow direct determination of coordinates of points (the documentation contained "only" linear measures between boundary points and elements of permanent development).

Such cases were e.g. confirmed by the results of the research carried out in 1998 regarding the land surveying documentation of the Bolechowice cadastral district of 640 ha, located in the commune of Zabierzów, east of Krakow. It was then found that, as a result of the subdivision of 120 cadastral parcels carried out in the years 1983-1995, 328 new plots were created, the boundaries of which were created by 1,843 boundary points. The coordinates in 20 geodetic surveys were given for only 274 points, which accounted for about $15 \%$ of the total number of boundary points of the new boundaries [44]. The situation in this area was still relatively good, because in other areas of Poland, especially in the ones covered by the Austrian cadastre until 1918, the number of surveys containing coordinates of points was much smaller [45].

The lack of important information about the documents describing the course of boundaries in the EGiB database is, according to the author, unacceptable and may cause serious damage. EGiB is a technical and declarative public register in Poland, and therefore it enters (records) data resulting from various proceedings and procedures carried out over the years, conducted based on various, often no longer applicable, legal provisions. This register cannot create or change the legal status of real properties, let alone distort (falsify) data regarding this state [46]. This is reflected in the legal regulations regarding the hierarchy of validity of the data on real estate boundaries. For example, for the purpose real estate subdivision proceedings, boundaries are adopted according to the legal status contained in land and mortgage registers, and not according to the status entered into the real estate cadastre [43].

As demonstrated in the Table 1, identical attributes of the boundary points 10 and 11 may apply to the boundary segment, which has a completely different status, and thus - a different "value" for the property owner. Therefore, it should be stated that as far as the database objects currently available in EGiB and their attributes regarding boundaries of cadastral parcels are concerned, it is not possible to provide the user with unambiguous and reliable information about the legal status of the boundary. The IT system managing such limited data is basically helpless when trying to determine the status of the boundary segment. 
Since 8 January 2014, the Regulation on the National Geodetic and Cartographic Resource (PZGiK) [47] has been in force, under which PZGiK collects digital copies of documents included in technical survey reports drawn up as a result of geodetic or cartographic works (including boundary sketches and protocols). The content of the PZGiK material register includes the information about the location of the area to which the resource material relates (the attribute "polozenieObszaru" referring to the dictionary "PZG_Polozenie") [47]. The "opis" attribute has the "CharacterString" type, so it is a completely non-standardised dictionary containing: "Summary, table of contents or a brief description of the content of the resource material" [47]. The very form of these digital copies of documents excludes automatic processing of the information stored in them, including the performance of appropriate analyses. These are usually files saved in raster form, resulting from the scanning of analogue documentation. The correct reading and classification of the data contained therein requires painstaking analyses as well as extensive knowledge and extensive surveying experience (these documents were created over many years in various technical, formal and legal environments). Neither the non-standardised description of documents, as mentioned earlier, nor linking these documents with surface areas (ranges) not directly related to parcel boundaries are useful for the automatic processing of these documents or determining the status of boundary segments therefrom.

The main obstacle in the correct reading of the information on parcel boundaries is the fact that the user of cadastral data obtains this data from the County Geodetic and Cartographic Documentation Centre (PODGiK) in the form of a computer file saved in the GML format compatible with the EGiB application schema. Therefore, such a file does not contain digital copies of the documents or the denotation (identifiers) of these documents as sources of relevant data.

This applies especially to the cases mentioned earlier, when these documents did not form the basis for determining the coordinates of the boundary points entered into the EGiB database. In order to obtain digital copies of documents regarding parcel boundaries, the user is required to pay an additional fee to PODGiK, followed by independent reading, classifying and linking the data contained in this documentation with the obtained EGiB data (e.g. identifying which parcel and which boundary segment is presented in the field sketch when the frequently analysed parcel was created as a result of many previous subdivisions). An additional difficulty when providing digital copies of documents is the need to ensure the protection of personal data. For this purpose, any personal data often found on boundary protocols or boundary sketches (surnames and names of owners and their home addresses) must be anonymised (blurred), which is quite expensive and time consuming.

It should also be mentioned that the current application schema of the EGiB database does not even provide for any relation (indications) for boundary points to the geodetic survey identifiers which the coordinates were obtained from. 
The circumstances described above indicate an urgent need to modify the current, inefficient model of the EGiB database by adding an object (class) regarding the boundary segment, named e.g. "EGB_OdcinekGranicyDzialkiEwidencyjnej". One of its attributes, in addition to the standard ones, inherited from the object "EGB_ OgolnyObiekt", should be a source of data on the course of the boundary segment with the two-level range of the list of values proposed in (Tab. 2).

Table 2. Summary of the proposed values of "ZRD" and "ZRDP" attributes for the boundary segment of the cadastral parcel

\begin{tabular}{|c|c|c|}
\hline ZRD & ZRDP & Description of boundary segment of cadastral parcel \\
\hline \multirow{5}{*}{1} & & Real estate delimitation \\
\hline & 101 & Real estate delimitation carried out in court proceedings \\
\hline & 102 & $\begin{array}{l}\text { Real estate delimitation concluded with a settlement referred to in Art. } 31 \text { section } 4 \\
\text { of the Act of } 17 \text { May } 1989 \text { Geodetic and Cartographic Law [6] }\end{array}$ \\
\hline & 103 & $\begin{array}{l}\text { Real estate delimitation carried out in administrative mode, concluded with a final } \\
\text { administrative decision }\end{array}$ \\
\hline & 104 & $\begin{array}{l}\text { Real estate delimitation carried out in administrative mode, but without covering } \\
\text { all parcels based on endpoints of boundary segment (remark: transitional attribute, } \\
\text { basically referring only to data from existing "archival" geodetic surveys) }\end{array}$ \\
\hline 2 & & $\begin{array}{l}\text { Boundaries not preceded by real estate delimitation, boundary markers restoration, } \\
\text { boundary points determination or defining their location in a different mode }\end{array}$ \\
\hline 3 & & Approved projects for real estate subdivision or consolidation and subdivision \\
\hline 4 & & Approved land consolidation or exchange projects \\
\hline \multirow{4}{*}{5} & & $\begin{array}{l}\text { Determining the course of boundaries under procedure set out in } \S 39 \\
\text { of the Regulation on EGiB [14] }\end{array}$ \\
\hline & 501 & $\begin{array}{l}\text { Determining (defining/identifying) the course of boundaries under procedure set } \\
\text { out in } \S 39 \text { section } 1 \text { of the Regulation on EGiB [14] }\end{array}$ \\
\hline & 502 & $\begin{array}{l}\text { Determining (defining/identifying) the course of boundaries under procedure set } \\
\text { out in } \S 39 \text { section } 2 \text { of the Regulation on EGiB [14] }\end{array}$ \\
\hline & 503 & $\begin{array}{l}\text { Determining (defining/identifying) the course of boundaries under procedure set } \\
\text { out in } \S 39 \text { section } 3 \text { of the Regulation on EGiB [14] }\end{array}$ \\
\hline \multirow{6}{*}{6} & & Boundaries determined in a different mode \\
\hline & 601 & Boundaries determined in proceedings regarding the establishment of EGiB [14] \\
\hline & 602 & $\begin{array}{l}\text { Boundaries determined pursuant to the Decree of } 21 \text { September } 1950 \text { on } \\
\text { delimitation of real estate owned by State Treasury or real estate purchased for the } \\
\text { implementation of national economic plans }\end{array}$ \\
\hline & 603 & $\begin{array}{l}\text { Boundaries determined in accordance with the Act of } 22 \text { May } 1958 \text { on areas for } \\
\text { construction of single-family houses in cities and housing estates }\end{array}$ \\
\hline & 604 & $\begin{array}{l}\text { Boundaries determined pursuant to Regulation of Minister of Local Economy } \\
\text { and Environmental Protection of } 28 \text { August } 1972 \text { regarding the procedure for } \\
\text { determination, delimitation and subdivision of areas for single-family and farm } \\
\text { construction in cities and housing estates }\end{array}$ \\
\hline & 605 & Other mode not specified above \\
\hline
\end{tabular}


Table 2 cont.

\begin{tabular}{||c|c|l||}
\hline \multirow{4}{*}{7} & 701 & Disputed boundary \\
\cline { 2 - 3 } & 702 & $\begin{array}{l}\text { Disputed boundary - dispute occurred during real estate delimitation } \\
\text { under the procedure specified in §39 of the Regulation on EGiB [14] }\end{array}$ \\
\cline { 2 - 3 } & 703 & $\begin{array}{l}\text { Disputed boundary - dispute occurred when determining the course of boundaries } \\
\text { carried out in a different mode }\end{array}$ \\
\hline
\end{tabular}

The first level with the "ZRD" code (Tab. 2 - column 1) is to refer to the general characteristics of the boundary segment, applicable during the transitional period, that is, until the detailed information (attributes) listed in column 2 (attribute with the "ZRDP" code) is entered for all boundaries. In some cases, this first, basic level is sufficient to correctly describe the status of the boundary (e.g. "3 - Approved projects for real estate subdivision or consolidation and subdivision"). Based on such attributes, further classifications and comparisons can be made automatically, e.g. in the following manner:

- determined boundaries - boundaries with ZRDP equal to "101", "102" or "103",

- disputed boundaries - boundaries with ZRD equal to "701", "702" or "703".

In the case of "determining" the course of boundaries pursuant to $\S 39$ of the Regulation on EGiB [14], the term "determination/identification" was additionally used to indicate the specificity of the results of this procedure, different from establishing the course of boundaries in delimitation proceedings regulated in [6], as described in more detail in $[10,23,25]$.

\section{Conclusions}

Incorrect legal regulations appearing in the applicable laws regarding the entering of boundaries of cadastral parcels into the register of land and buildings (EGiB) lead to:

- the reduced reliability of the data by:

- the inability to fully and precisely enter the captured data into the EGiB database, which leads to distortion of the information made available to users;

- the need to minimise the use of materials from PZGiK by contractors due to their costs (the fee depends on the number of materials obtained from PZGiK);

- the waste of:

- the financial resources (public or private) due to the need to re-capture the necessary data in the future or its tedious verification;

- the efforts of many people involved in maintaining the EGiB survey (surveyors, employees of PODGiK);

- the time and commitment of the property owners participating in surveying and legal activities regarding parcel boundaries. 
The procedures regarding the boundaries of cadastral parcels (capturing, determining, entering) and the attributes assigned to parcel boundary points should be sorted out. A new class should be added to the EGiB application schema regarding the boundary segment of the parcel, which will allow:

- the correct entering of boundary data, e.g. if PODGiK is supplied with the data concerning only one boundary segment, e.g. subject to delimitation proceedings, and the other segments do not have appropriate digital data (they appear only on the analogue cadastral map);

- the correct entering of information on the status of the boundary segment (e.g. determined, undetermined, not being determined, disputed);

- flexible data sharing ("part of a parcel, not the whole parcel") and the related calculation of adequate fees for the use of data, as well as the efficient supply of data to the PODGiK database by surveying contractors (the so-called minimum blocking of the base at PODGiK).

\section{References}

[1] Zarzadzenie Ministrów Rolnictwa i Gospodarki Komunalnej z dnia 20 lutego 1969 r. w sprawie ewidencji gruntów. M.P. 1969 nr 11, poz. 98 z późn. zm. [Ordinance of the Ministers of Agriculture and Municipal Economy of 20 February 1969 on land registry. Official Gazette of 1969, no. 11, item 98 as amended].

[2] Rozporządzenie Ministrów Gospodarki Przestrzennej i Budownictwa oraz Rolnictwa i Gospodarki Żywnościowej z dnia 17 grudnia 1996 r. w sprawie ewidencji gruntów i budynków. Dz.U. 1996 nr 158, poz. 813 [Regulation of Ministers of Land Management and Construction as well as Agriculture and Food Economy of 17 December 1996 on the register of land and buildings. Journal of Laws of 1996, no. 158, item 813].

[3] Instrukcja techniczna K-1: Podstawowa mapa kraju, wprowadzona do stosowania przez Głównego Geodetę Kraju pismem z dnia 16 maja 1995 r. [Technical Guideline K-1: The base map of the country, introduced for use by the Surveyor General of Poland in a letter of 16 May 1995].

[4] Instrukcja techniczna K-1: Mapa zasadnicza. Wyd. 3. Główny Geodeta Kraju, Warszawa 1998 [Technical Guideline K-1: The base map. $3^{\text {rd }}$ ed. Surveyor General of Poland, Warsaw 1998].

[5] Rozporządzenie Ministra Spraw Wewnętrznych i Administracji z dnia 24 marca 1999 r. w sprawie standardów technicznych dotyczacych geodezji, kartografii oraz krajowego systemu informacji o terenie. Dz.U. 1999 nr 30, poz. 297 [Regulation of the Minister of the Interior and Administration of 24 March 1999 on technical standards regarding geodesy, cartography and the national land information system. Journal of Laws of 1999, no. 30, item 297]. 
[6] Ustawa z dnia 17 maja 1989 r. Prawo geodezyjne i kartograficzne. Tekst jednolity: Dz.U. 2020 poz. 276 [Act of 17 May 1989 Geodetic and Cartographic Law. Consolidated text: Journal of Laws of 2020, item 276].

[7] Directives Directive 2007/2/EC of The European Parliament and of The Council of 14 March 2007 establishing an Infrastructure for Spatial Information in the European Community (INSPIRE). Official Journal of the European Union No L 108/1.

[8] Ustawa z dnia 4 marca 2010 r. o infrastrukturze informacji przestrzenne. Tekst jednolity: Dz.U. 2020 poz. 177 [Act of 4 March 2010 on spatial information infrastructure. Consolidated text of Journal of Laws of 2020, item 177].

[9] Maślanka J.: Ustalanie przebiegu granic działek ewidencyjnych w trybie przepisów o ewidencji gruntów i budynków oraz wykazywanie ustalonych granic w bazach ewidencyjnych - wybrane aspekty formalno-prawne i technologiczne [Determining the course of the boundaries of cadastral parcels pursuant to the provisions on the register of land and buildings and entering the determined boundaries into cadastral databases - selected formal, legal and technical aspects]. Infrastruktura i Ekologia Terenów Wiejskich, nr III/1, 2018, pp. 741-754. https://doi.org/10.14597/ INFRAECO.2018.3.1.050.

[10] Maślanka J.: Restoration of Boundary Markers and the Determination of Boundary Points in the Context of the Reliability of the Register of Land and Buildings. Geomatics and Environmental Engineering, vol. 13, no. 4, 2019, pp. 49-65. https://doi.org/10.7494/geom.2019.13.4.49.

[11] Pęska-Siwik A., Hanus P.: Punkt graniczny $i$ źródła danych o jego położeniu (atrybut ZRD) [The boundary point and source of data about its location (attribute ZRD)]. Przegląd Geodezyjny, r. 90, nr 8, 2018, pp. 14-18. https://doi.org/10.15199/50.2018.8.2.

[12] Pęska-Siwik A.: Charakterystyka wybranych prac geodezyjnych zwiazanych $z$ określaniem przebiegu granic działki ewidencyjnej w kontekście atrybutu ZRD [Charecteristics of setected geodetic works related to determining the course of $\mathrm{ca}$ dastral plot boundaries in the ZRD attribute context]. Przegląd Geodezyjny, r. 92, nr 1, 2020, pp. 16-20.

[13] Rozporzadzenie Rady Ministrów z dnia 7 grudnia 2004 r. w sprawie sposobu i trybu dokonywania podziatów nieruchomości. Dz.U. 2004 nr 268, poz. 2663 [Regulation of the Council of Ministers of 7 December 2004 on the manner and procedure for real estate subdivision. Journal of Laws of 2004, no. 268, item 2663].

[14] Rozporzadzenie Ministra Rozwoju Regionalnego i Budownictwa z dnia 29 marca 2001 r. w sprawie ewidencji gruntów i budynków. Tekst jednolity: Dz.U. 2019 poz. 393 [Regulation of the Minister of Regional Development and Construction of 29 March 2001 on the register of land and buildings. Consolidated text: Journal of Laws of 2019, item 393]. 
[15] Rozporzadzenie Ministra Administracji i Cyfryzacji z dnia 29 listopada 2013 r. zmieniajace rozporządzenie w sprawie ewidencji gruntów i budynków. Dz.U. 2013 poz. 1551 [Regulation of the Minister of Administration and Digitization of $29 \mathrm{No}$ vember 2013 amending the regulation on the register of land and buildings. Journal of Laws of 2013, item 1551].

[16] Stanowisko nr 24/2013/K-P Konwentu Marszałków Województw RP z dnia 20 września 2013 r. w sprawie poparcia działań majacych na celu przyspieszenie modernizacji ewidencji gruntów i budynków jako podstawowego elementu infrastruktury informacji przestrzennej [Stand No. 24/2013/K-P of the Convention of Marshals of Provinces of the Republic of Poland of 20 September 2013 on support for actions aimed at accelerating the modernization of the register of land and buildings as a basic element of spatial information infrastructure]. http://geoforum.pl/upload/files/pliki/130926_stanowisko.pdf [access: 25.02.2020].

[17] Morawiecki L.: Wstẹp do prawoznawstwa. Towarzystwo Naukowe Organizacji i Kierownictwa, Toruń 1999.

[18] Chauvin T., Stawecki T., Winczorek P.: Wstęp do prawoznawstwa. Wyd. 13. Wydawnictwo C.H.BECK, Warszawa 2018.

[19] Słownik jezzyka polskiego PWN. https://sjp.pwn.pl [access: 25.02.2020].

[20] Wielki słownik języka polskiego. https://wsjp.pl [access: 25.02.2020].

[21] Gaździcki J.: Systemy informacji przestrzennej. Państwowe Przedsiębiorstwo Wydawnictw Kartograficznych, Warszawa - Wrocław 1990.

[22] Pęska-Siwik A.: Ustalenie przebiegu granic nieruchomości w aspekcie wiarygodności wybranych atrybutów działki ewidencyjnej. Kraków 2017 [Ph.D. thesis, unpublished].

[23] Maślanka J.: Determining the course of boundaries based on points shared by several properties and entering this data into the register of land and buildings. Infrastruktura i Ekologia Terenów Wiejskich, nr IV/1/2018, pp. 879-890. https://doi.org/10.14597/INFRAECO.2018.4.1.060.

[24] Maślanka J.: Koncepcja modernizacji ewidencji gruntów i budynków w aspekcie potrzeb harmonizacji i interoperacyjności baz danych ewidencyjnych. Krakow 2015 [Ph.D. thesis, unpublished].

[25] Maślanka J.: Restoration of boundary markers and the determination of boundary points - proposed amendments to the laws of Poland. Geomatics and Environmental Engineering, vol. 14, no. 1, 2020, pp. 87-97. https://doi.org/10.7494/ geom.2020.14.1.87.

[26] Rozporzadzenie Ministra Administracji i Cyfryzacji z dnia 6 listopada 2015 r. zmieniajace rozporządzenie w sprawie ewidencji gruntów i budynków. Dz.U. 2015 poz. 2109 [Regulation of the Minister of Administration and Digitization of 6 November 2015 amending the regulation on the register of land and buildings. Journal of Laws of 2015, item 2109]. 
[27] Wyrok WSA w Krakowie z 30.08.2018 r. Nr III SA/Kr 319/18 [Judgement of the Provincial Administrative Court in Krakow of 30.08.2018 Ref. No. III SA/Kr 319/18]. http://orzeczenia.nsa.gov.pl/doc/EBFCF4E4EB [access: 25.02.2020].

[28] Wyrok WSA w Krakowie z 19.09.2018 Nr III SA/Kr 732/18 [Judgement of the Provincial Administrative Court in Krakow of 19.09.2018 Ref. No. III SA/Kr 732/18]. http://www.orzeczenia-nsa.pl/wyrok/iii-sa-kr-732-18/ ewidencja_gruntow_i_budynkow/b106be.html [access: 25.02.2020].

[29] Wyrok WSA w Krakowie z 22.11.2018 Nr III SA/Kr 895/18 [Judgement of the Provincial Administrative Court in Krakow of 22.11.2018 Ref. No. III SA/Kr 895/18]. http://orzeczenia.nsa.gov.pl/doc/5A9132565E [access: 25.02.2020].

[30] INSPIRE_DataSpecification_CP_v3.1.doc. http://inspire-regadmin.jrc.ec.europa.eu/dataspecification/DataQuality.action?hideMenu=\&themeId1=cp [access: 25.02.2020].

[31] Rozporzadzenie Ministra Administracji i Cyfryzacji z dnia 2 listopada 2015 r. w sprawie bazy danych obiektów topograficznych oraz mapy zasadniczej. Dz.U. 2015 poz. 2028 [Regulation of the Minister of Administration and Digitization of 2 November 2015 on the database of topographic objects and the base map. Journal of Laws of 2015, item 2028].

[32] Rozporzadzenie Ministra Spraw Wewnętrznych i Administracji z dnia 9 listopada 2011 r. w sprawie standardów technicznych wykonywania geodezyjnych pomiarów sytuacyjnych $i$ wysokościowych oraz opracowywania i przekazywania wyników tych pomiarów do państwowego zasobu geodezyjnego i kartograficznego. Dz.U. $2011 \mathrm{nr}$ 263, poz. 1572 [Regulation of the Minister of Internal Affairs and Administration of 9 November 2011 on technical standards for the performance of plane and vertical land surveys as well as elaboration and transfer of the results to the national geodetic and cartographic resource. Journal of Laws of 2011, no. 263, item 1572].

[33] Ustawa z dnia 21 sierpnia 1997 r. o gospodarce nieruchomościami. Tekst jednolity: Dz.U. 2020 poz. 65 [Act of 21 August 1997 on real estate management. Consolidated text of Journal: Laws of 2018, item 65].

[34] Ustawa z dnia 10 kwietnia 2003 r. o szczególnych zasadach przygotowania i realizacji inwestycji w zakresie dróg publicznych. Tekst jednolity: Dz.U. 2018 poz. 1474 z późn. zm. [Act of 10 April 2003 on specific principles for the preparation and implementation of investments in public roads. Consolidated text: Journal of Laws of 2018, item 1474, as amended].

[35] Podziaty przez potracenie do lamusa? https://geoforum.pl/news/25496/podzialy-przez-potracenie-do-lamusa- [access: 25.02.2020].

[36] Wyrok WSA w Gliwicach z 17.12.2015 r. Nr II SA/Gl 800/15 [Judgement of the Provincial Administrative Court in Gliwice of 17.12.2015 Ref. No II SA/ Gl 800/15]. http://orzeczenia.nsa.gov.pl/doc/50B12A1222 [access: 25.02.2020]. 
[37] Wyrok WSA w Gliwicach z 11.06.2018 r. Nr II SA/Gl 88/18 [Judgement of the Provincial Administrative Court in Gliwice of 11.06.2018 Ref. No II SA/Gl 88/18]. http://www.orzeczenia-nsa.pl/wyrok/ii-sa-gl-88-z/zasob_geodezyjny_i_kartograficzny/78743f.html [access: 25.02.2020].

[38] Starosta Wielicki: Stanowisko w sprawie sprawozdania z kontroli doraźnej w trybie uproszczonym $n r$ IGI.431.4.1.2017.AP (GK.664.1.2.2017) [District Governor of Wieliczka: Stand on the report on summary control under the simplified procedure No. IGI.431.4.1.2017.AP (GK.664.1.2.2017)]. Wieliczka 2018 [unpublished].

[39] EWMAPA - instrukcja do programu. Geobid Sp. z o.o., Katowice 2016.

[40] Aktualizacja bazy danych EWID 2007 po modernizacji za pomoca GML. https://geomatyka-krakow.pl/portal/index.php/wsparcie/opisytechnologii/ 120-aktualizacja-bazy-danych-ewid-2007-po-modernizacji-za-pomoca-gml [accsess: 25.02.2020].

[41] Podręcznik użytkownika programu EWMAPA. Geobid Sp. z o.o., Katowice 2005.

[42] Malinowska A.: Autoreferat - załacznik do wniosku z dnia 6 maja 2016 r. o przeprowadzenie postepowania habilitacyjnego. Website of the Faculty of Mining Surveying and Environmental Engineering of AGH: http://www.geod.agh. edu.pl/files/habilitacje/malinowska/autoreferat.pdf [access: 25.05.2020].

[43] Rozporzadzenie Ministrów Spraw Wewnętrznych i Administracji oraz Rolnictwa $i$ Gospodarki Żywnościowej z dnia 14 kwietnia 1999 r. w sprawie rozgraniczania nieruchomości. Dz.U. 1999 nr 45, poz. 453 [Regulation of the Ministers of Internal Affairs and Administration as well as Agriculture and Food Economy of 14 April 1999 on real estate delimitation. Journal of Laws of 1999, no. 45, item 453].

[44] Latoś S., Maślanka J.: Analiza dokładności map numerycznych i cyfrowych [Accuracy analysis of numerical and digital maps]. Geodezja - Akademia Górniczo-Hutnicza im. Stanisława Staszica w Krakowie, t. 6, z. 2, 1998, pp. 163-177.

[45] Maślanka J.: Zrozumieć SIT. Magazyn Geodezyjny GEODETA, nr 11(18), 1996, pp. 5-8.

[46] Wyrok NSA w Warszawie z 18.04 .1999 r. Nr II SA 1632/98 [Judgement of the Supreme Administrative Court in Warsaw of 18.04.1999 Ref. No. II SA 1632/98]. https://sip.lex.pl/orzeczenia-i-pisma-urzedowe/orzeczenia-sadow/ii-sa-1632-98-wyrok-naczelnego-sadu-administracyjnego-520139912 [access: 25.02.2020].

[47] Rozporzadzenie Ministra Administracji i Cyfryzacji z dnia 5 września 2013 r. w sprawie organizacji i trybu prowadzenia państwowego zasobu geodezyjnego $i$ kartograficznego. Dz.U. 2013 poz. 1183 [Regulation of the Minister of Administration and Digitization of 5 September 2013 on the organization and mode of keeping the National Geodetic and Cartographic Resource. Journal of Laws of 2013, item 1183]. 


\section{Rejestrowanie granic działek w polskiej ewidencji gruntów i budynków - analiza obecnego stanu i propozycje zmian}

Streszczenie: Polska ewidencja gruntów i budynków (EGiB), nazywana też katastrem nieruchomości, ma charakter techniczno-deklaratoryjny, co oznacza, że powinna wiernie rejestrować w bazie EGiB, a następnie udostępniać bez zniekształceń i braków dane powstałe $\mathrm{w}$ wyniku specjalnych procedur technicznych i formalno-prawnych. Przedmiotem artykułu jest analiza problemów formalno-prawnych i technologicznych występujących w zakresie rejestrowania w EGiB danych dotyczących granic działek ewidencyjnych. Autor na podstawie przepisów prawa, literatury przedmiotu, a także przypadków zaczerpniętych z praktyki geodezyjnej dokonuje opisowej analizy formalnej i porównawczej obecnych rozwiązań prawnych oraz technologicznych stosowanych do rejestrowania granic działek w bazie danych EGiB. W ich wyniku przeprowadzonych analiz autor stwierdza, że obecne rozwiązania prawne, nie pozwalają na pełne i prawidłowe rejestrowanie, a także przekazywanie użytkownikom danych dotyczących granic działek powstałych w wyniku przeprowadzonych prac geodezyjno-prawnych. Stwierdzone braki, trudności i bariery w zakresie rejestrowania danych dotyczących granic mogą prowadzić do zniekształcanie powstałych na ich bazie informacji, a - co za tym idzie - do obniżenia wiarygodności EGiB. Autor proponuje wprowadzenie do schematu aplikacyjnego określającego strukturę bazy ewidencyjnej pojęcia odcinka granicy wraz z odpowiednimi atrybutami, co pozwoli na usunięcie wielu dotychczasowych problemów oraz na dostarczanie użytkownikom EGiB wiarygodnych i pełnych informacji.

Słowa

kluczowe: kataster, ewidencja gruntów i budynków, granice działek ewidencyjnych, punkty graniczne działek 